Research Note

\title{
POLLEN COLLECTION AND BROOD PRODUCTION BY HONEYBEES (Apis mellifera L.) UNDER CHITWAN CONDITION OF NEPAL
}

\author{
K. R. Neupane and R. B. Thapa \\ Institute of Agriculture and Animal Sciences, Rampur, Chitwan, Nepal
}

\begin{abstract}
A study was carried out to investigate pollen foraging, storage and its impact on Apis mellifera $\mathrm{L}$ brood production throughout the year under Terai condition of Nepal in 2003-2005. Number of pollen foragers, amount of pollen stored as beebread and brood in the colony differed significantly during different seasons. Number of pollen foragers (117.5 bees/ hive/ $5 \mathrm{~min})$ and amount of pollen as beebread ( $2439.0 \mathrm{gm} / \mathrm{hive})$ and number of brood (14787.2 brood cells/hive) were the highest during spring season, while the lowest number of pollen foragers ( 38.1 bees/ hive/ 5 min.) stored the lowest amount of beebread or pollen store (152.5 gm / hive) and produced the lowest number of brood (3811.7 brood cells/ hive) and bees in rainy season. Autumn, winter and summer seasons were normal for pollen collection and brood production, while starvation and nutritional deficiencies due to the acute shortage of pollen in rainy season was the major reason to decline or collapse the bee population before the honey flow season. Therefore, feeding bees with adequate amount of nutritionally rich pollen during rainy season is essential to maintain a healthy and strong bee colony for the production of higher honey and other hive products.
\end{abstract}

Key words: Honeybees, foraging, pollen, brood, Apis mellifera

\section{INTRODUCTION}

Flowers are the mainstay of the bee's life from where they collect pollen (protein rich food) and nectar (major source of energy). Growth of bees begins as soon as newly merged bee starts feeding on pollen with a development of their brood food glands, fat bodies and other tissues. Pollen eating age in the worker bees ranges from emerging to 18 days old. However, the maximum amount of pollen consumption occurs when bees are 5 days old. The protein content of fresh weight of emerging bees is $13 \%$ and $15.5 \%$ of fresh weight of 5 days old bees (Dietz, 1975). During the early adult life of worker bees, all nitrogen is derived from pollen protein. Therefore, young worker must consume a large amount of pollen in the first two weeks of their adult life. Therefore, the amount of pollen inside the hive is a crucial factor for the proper development of healthy honeybees and strong bee colony. The key indicators for the proper health and development of bees are vitamin A, B1, B2, B6 and folic acid and minerals such as iron, manganese and zinc in the pollen (Dietz, 1975; Vivino and Palmer, 1994). Nutrition of honeybees involves various chemicals such as carbohydrates, fats, proteins, minerals and vitamins.

Nectar and pollen collection foraging by bees is a continuous process throughout the year in tropical and sub-tropical areas, where there is continuous succession of blooming of bee flora. However, the foraging activities of honeybees for pollen are greatly influenced by the weather conditions and availability of pollen. In tropical and sub-tropical areas, summer and rainy seasons are very harsh for bees. Generally no floral sources are available to bees from June to September (Mishra and Sharma, 1997-98). Food shortage cause quick dwindling and even death of bee colonies. Therefore, the amount of incoming pollen in a bee colony may vary according to different seasons of Nepal, which plays a very important role for the production of brood and bees.

\section{MATERIALS AND METHODS}

This study was carried out at Gorkha Bee Farm, Yagyapuri, Chitwan, Nepal. Six Apis mellifera L. honeybee colonies each having 10 frames of bees and 4 frames of brood and queen of similar age and quality were selected to carry out the study in autumn, winter, spring, summer and rainy seasons from 2003 to 2005 . Number of brood and pollen cells were counted and recorded during autumn, winter, spring, summer and rainy seasons with the help of brood measurement table developed by Woyke (1976). Number of pollen foragers for the bees, which were coming with pollen loads at the hive entrance was counted for five minutes in each bee colony 
during peak foraging periods of the day. Comparative study for the number of pollen foragers, pollen and brood cells in the brood nest of each experimental colony were done for different seasons under Terai condition of Nepal.

\section{RESULTS AND DISCUSSION}

The number of bee brood and pollen cells in the brood nest and number of pollen foragers varied during different seasons under Chitwan condition of Nepal (Table 1) The findings revealed that the production of bee brood was the highest (14787.20 \pm 3094.92 brood cells/hive) during spring followed by summer

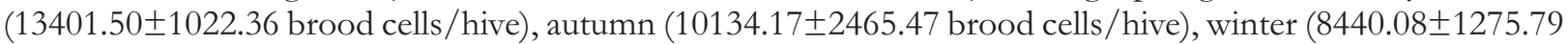
brood cells/hive) and the lowest ( $3811.17 \pm 609.94$ brood cells / hive) during rainy season. The worker population of honeybee colonies was higher during spring followed by summer, winter, autumn and the lowest during rainy season, respectively.

The number of pollen storage was the highest (2439.00 \pm 625.80 pollen cells/hive) during spring season followed by winter ( $2336.08 \pm 488.58$ pollen cells / hive), autumn ( $1439.67 \pm 185.22$ pollen cells/hive), summer ( $973.80 \pm 2351.53$ pollen cells/hive) and the lowest (50.83 \pm 12.52 pollen cells/hive) during rainy season. Large amount of surplus pollen stored was observed during spring and winter, while it was normal during autumn and summer seasons. However, the pollen storage was recorded the lowest during rainy season, which was too low for the fulfilment of bees.

Table 1. Performance of A. mellifera bee colonies in different seasons under Chitwan condition of Nepal, 2003/2005

\begin{tabular}{|c|c|c|c|c|c|}
\hline Feeding treatments & $\begin{array}{l}\text { Brood cells per } \\
\text { colony (No.) }\end{array}$ & $\begin{array}{l}\text { Pollen cells per } \\
\text { colony (No.) }\end{array}$ & $\begin{array}{l}\text { Pollen forager } \\
\text { per colony } \\
(\text { No. } / 5 \text { min })\end{array}$ & $\begin{array}{c}\text { Outgoing bees } \\
\text { per colony } \\
\text { (No./5 min) }\end{array}$ & $\begin{array}{c}\text { Incoming bees } \\
\text { per colony } \\
\text { (No. } / 5 \mathrm{~min} \text { ) }\end{array}$ \\
\hline Autumn season & $10134.17 \pm 2465.47$ & $1439.67 \pm 185.22$ & $62.25 \pm 7.29$ & $263.82 \pm 28.61$ & $206.67 \pm 21.82$ \\
\hline Winter season & $8440.08 \pm 1275.79$ & $2336.08 \pm 488.58$ & $63.17 \pm 11.79$ & $334.25 \pm 35.80$ & $339.75 \pm 24.18$ \\
\hline Spring season & $14787.20 \pm 3094.92$ & $2439.00 \pm 625.80$ & $117.50 \pm 22.63$ & $358.83 \pm 28.40$ & $359.17 \pm 24.06$ \\
\hline Summer season & $13401.50 \pm 1022.36$ & $973.80 \pm 2351.53$ & $64.58 \pm 6.97$ & $267.50 \pm 21.46$ & $209.33 \pm 30.04$ \\
\hline Rainy season & $3811.17 \pm 609.94$ & $50.83 \pm 12.52$ & $38.08 \pm 7.27$ & $28.92 \pm 3.40$ & $43.00 \pm 5.90$ \\
\hline
\end{tabular}

Average of six replications, values after \pm indicate SE

It was found that the pollen foragers were the highest (117.50 \pm 22.63 bees / hive / 5 min.) during spring season followed by summer ( $64.58 \pm 6.97$ bees / hive / 5 min.), winter ( $63.17 \pm 11.79$ bees/ hive/ 5 min.), autumn (62.25 \pm 7.29 bees/ hive/ $5 \mathrm{~min}$.) and the lowest ( $38.08 \pm 7.27$ bees / hive/ $5 \mathrm{~min}$.) during rainy season. Pollen load of the foragers was considerably bigger during spring, summer, autumn and winter than in rainy season. The honeybees collected pollen mostly in the morning hours of the day during all seasons.

Table 2. Seasonal variation on brood and pollen cells of $A$. mellifera under Chitwan condition of Nepal, 2003/2005

\begin{tabular}{|llcr|}
\hline Date and Month & Season & Brood cells per colony (No.) & Pollen cells per colony (No.) \\
\hline 15- October & Winter & $14939.00 \pm 966.46$ & $1439.00 \pm 235.06$ \\
07- November & Winter & $23450.00 \pm 2964.12$ & $7866.60 \pm 6088.99$ \\
08- December & Winter & $14187.60 \pm 934.05$ & $3408.20 \pm 820.71$ \\
01- January & Spring & $14768.60 \pm 1659.79$ & $1451.40 \pm 322.25$ \\
22- February & Spring & $19940.60 \pm 2299.67$ & $514.20 \pm 104.83$ \\
16- March & Spring & $21681.00 \pm 3224.13$ & $835.40 \pm 76.04$ \\
26- April & Summer & $11689.00 \pm 1426.95$ & $1946.40 \pm 378.72$ \\
17- May & Summer & $19652.80 \pm 2069.24$ & $3275.60 \pm 351.92$ \\
08- June & Summer & $21080.20 \pm 1878.20$ & $3690.00 \pm 1133.22$ \\
04- July & Rainy & $17687.80 \pm 2051.53$ & $1230.80 \pm 188.33$ \\
08 August & Rainy & $15920.40 \pm 2341.99$ & $33.80 \pm 5.68$ \\
19- September & Rainy & $21540.20 \pm 2335.18$ & $421.40 \pm 46.25$ \\
\hline
\end{tabular}

Average of six replications, values after \pm indicate $\mathrm{SE}$ 
The collection of pollen by worker bees was influenced by number of factors including both internal and external. Higher number of brood in the colony stimulated the foragers to collect higher amount of pollen. External factors, such as temperature, light, wind, rain, cloud, humidity also influenced the pollen foraging activities.

The brood production in the colony initiated with the beginning of autumn season with the availability of natural pollen and suitable climate. The number of pollen foragers was recorded 62.3/colony during autumn when air temperature ranged from 34 to $19^{\circ} \mathrm{C}$ with a relative humidity of 85 to $87 \%$ (Table 4). The air temperature played main role to influence the worker bees to collect pollen. Lauveaux $(1958 / 59)$ observed that pollen was not collected when air temperature was below $10^{\circ} \mathrm{C}$. The increased pollen storage with the increased number of pollen foragers also increased the number of brood production during the later part of autumn season. So, the production of brood at initial time of autumn season is very important for the production of enough field force for higher honey production during forth coming season.

Storage of pollen was found sub-optimal, which is used as a source of proteins, lipids and vitamins for developing larvae and initiate more brood at the beginning of autumn. Therefore, it is very important to provide the protein rich food for bees in sufficient amount during rainy and the beginning of autumn seasons to keep bees healthy and strong. However, this situation may vary from place to place, and hence, colony needs management accordingly.

The study revealed that the production of brood declined during winter months especially due to the unfavorable climatic condition. The range of temperature during winter months in the Terai region is 24 to $9^{\circ} \mathrm{C}$ (Table 4), which affects both inside hive and field activities of bees. Camareno and Pecho (1973) and Verma,(1995) claimed $25^{\circ} \mathrm{C}$ as a peak foraging temperature for mellifera bees. According to Mishra and Sharma (1997/98), worker bees of mellifera stopped foraging when air temperature dropped down below $14^{\circ} \mathrm{C}$ and lost ability to move at temperature below $10^{\circ} \mathrm{C}$. In addition, field activities of bees are badly affected by cloudy days, foggy mornings and rains during the months of winter season. Worker bees from super are shifted to brood chamber as winter cluster for protecting the broods. Higher numbers of bees are involved to maintain the brood nest temperature during winter months instead of going for foraging pollen and nectar. Therefore, climatic elements are the limiting factors during winter season.

Spring season is the best among all the seasons under Terai condition of Nepal for bee activities and production of different hive products. The suitable, climate such as optimum air temperature, humidity, open and sunny days for longer duration and low wind velocity for foraging and availability of enough pollen and nectar from different flora stimulated the highest number of worker bees to collect maximum amount of pollen and produced higher number of broods (Table 1, 2, 3). High level of natural pollen collected by bees provides high dose of protein for newly emerged bees. Generally the protein content of pollen ranges from 8 to $40 \%$. Bees, which are sufficiently fed with high protein content pollen produce large quantities of royal jelly to feed to laying queen and young larvae. When laying queen receives more amount of royal jelly, she lays more eggs and produces more pheromones. The larger number of broods and increased amount of queen pheromones stimulates bees to collect more pollen and nectar. Those worker bees which receive enough protein rich food become healthy, live long and are highly productive for different bee products including royal jelly, bee wax, bee venom (Mattila and Otis, 2003; Otis et al., 2003). Therefore, the spring season has been found the best season for the production of brood, pollen, honey, royal jelly, and bee venom and queen bees. In addition, spring season is also the best time for the building of comb foundations.

It has been found from the experiment that the production of brood and store of pollen started to decline from the months of summer season (Table 1,2). Climatic condition and availability of bee flora are the major limiting factors to decline the brood and pollen in the summer season. The high temperature, which ranges from 22 to $34^{\circ} \mathrm{C}$ and low humidity ranging from 75 to $77 \%$, cloudy days, rains and storms during summer reduced the collection of pollen (Table 3). Hayad (1935) reported 34 to $19^{\circ} \mathrm{C}$ temperature and 87 to $85 \%$ relative humidity optimum for foraging of mellifera bees. Because of higher day temperature bees are active during mornings and afternoon hours for foraging. Mishra and Sharma (1997/98) reported that the foraging activities of mellifera bees for pollen and nectar started to decline when air temperature exceeded $35^{\circ} \mathrm{C}$ and stopped at $40^{\circ} \mathrm{C}$. Dry and hot air temperature causes to desiccate pollen and nectar of the flowers thus making 
them unavailable to bees during summer. Therefore, the store of pollen and honey in the colony may not be sufficient for bees in some part of Terai region of Nepal during summer months, and hence, should be given enough food to manage the colonies properly.

Table 3. Temperature, rainfall and humidity of Chitwan

\begin{tabular}{|c|c|c|c|c|}
\hline \multirow{2}{*}{ Date } & \multicolumn{2}{|c|}{ Temperature $\left({ }^{0} \mathrm{C}\right)$} & \multirow[b]{2}{*}{ Rain (mm) } & \multirow[b]{2}{*}{ RH (\%) } \\
\hline & Max & Min & & \\
\hline Jan1-7 & 21.1 & 9.6 & 3.9 & 95.5 \\
\hline Jan8-14 & 17.4 & 6.8 & 0.0 & 94.1 \\
\hline Jan 15-21 & 21.4 & 6.4 & 0.0 & 99.9 \\
\hline $\operatorname{Jan} 22-30$ & 21.7 & 7.5 & 0.0 & 98.0 \\
\hline 7-Feb & 22.2 & 11.5 & 3.2 & 99.1 \\
\hline 14-Feb & 26.7 & 9.6 & 0.0 & 100 \\
\hline 21-Feb & 25.3 & 8.4 & 0.0 & 97.2 \\
\hline Feb-30 & 26.4 & 11.4 & 17.5 & 99.1 \\
\hline March & 29.4 & 14.4 & 9.5 & 92.5 \\
\hline March & 27.5 & 9.4 & 0.0 & 86.8 \\
\hline March & 29.1 & 14.3 & 0.0 & 85.2 \\
\hline March & 30.6 & 15.7 & 6.7 & 84.0 \\
\hline April & 31.9 & 17.0 & 0.8 & 79.8 \\
\hline April & 34.1 & 17.7 & 0.06 & 72.8 \\
\hline April & 35.2 & 18.4 & 6.7 & 69.5 \\
\hline April & 35.4 & 20.6 & 1.0 & 17.0 \\
\hline May & 34.4 & 22.1 & 5.7 & 72.1 \\
\hline May & 34.9 & 20.1 & 8.6 & 68.2 \\
\hline May & 35.5 & 19.8 & 1.9 & 60.0 \\
\hline May & 35.3 & 21.2 & 6.3 & 67.1 \\
\hline June & 36.1 & 22.5 & 4.4 & 72.4 \\
\hline June & 37.3 & 24.9 & 4.9 & 75.3 \\
\hline June & 33.9 & 23.9 & 8.8 & 81.9 \\
\hline June & 35.0 & 24.2 & 16.5 & 87.4 \\
\hline July & 33.4 & 24.7 & 22.6 & 96.0 \\
\hline July & 32.8 & 25.1 & 24.5 & 97.0 \\
\hline July & 32.3 & 25.1 & 32.6 & 86.6 \\
\hline July & 33.7 & 25.0 & 17.1 & 92.0 \\
\hline August & 33.9 & 25.3 & 24.6 & 87.6 \\
\hline August & 34.9 & 26.2 & 44.0 & 79.4 \\
\hline August & 34.3 & 25.5 & 8.6 & 80.9 \\
\hline August & 29.5 & 25.8 & 14.9 & 82.3 \\
\hline September & 31.5 & 25.4 & 42.2 & 88.6 \\
\hline September & 34.9 & 25.7 & 6.0 & 86.3 \\
\hline September & 33.9 & 25.4 & 14.5 & 85.3 \\
\hline September & 33.8 & 25.4 & 3.9 & 80.0 \\
\hline October & 34.0 & 25.5 & 3.1 & 85.9 \\
\hline October & 31.8 & 24.1 & 18.4 & 91.6 \\
\hline October & 28.3 & 19.8 & 2.7 & 84.5 \\
\hline October & 33.1 & 22.3 & 0.1 & 81.6 \\
\hline November & 33.8 & 21.5 & 0.0 & 86.4 \\
\hline November & 32.5 & 27.7 & 0.0 & 93.1 \\
\hline November & 31.0 & 20.2 & 11.3 & 89.4 \\
\hline November & 30.3 & 17.4 & 0.0 & 93.2 \\
\hline December & 22.2 & 17.1 & 0.0 & 89.8 \\
\hline December & 29.0 & 14.3 & 0.0 & 92.8 \\
\hline December & 27.7 & 12.6 & 0.0 & 98.5 \\
\hline December & 24.8 & 10.6 & 0.0 & 100 \\
\hline
\end{tabular}

Weather data obtained from National Maize Research Center, Rampur, 2003 
The studies have shown that the bees collected and stored the lowest amount of pollen (Table 1) and produced the least number of broods during rainy season. Unfavorable climate and lack of bee flora are the major limiting factors for the shortage of pollen and decline in brood production during rainy season. Continuous heavy rains for several days washes the pollen grains thereby making them unavailable for bees. Cloudy weather and continuous rains for many days reduces or stops the foraging activities of bees for a long time. In addition, lack of sufficient number of bee flora for providing good quality pollen and nectar in abundance is another limiting factor for bees in Terai and mid hills of Nepal during rainy season. All these factors together results in poor collection of pollen. Worker population in the colony sharply declines or collapses due to very less production of brood. Starvation is one of the most common cases of weak or collapse of colony during rainy season in tropical and sub-tropical region. Rashad and Parker (1958) reported that each larva needs more than $100 \mathrm{mg}$ of pollen for its complete development. According to them, one cell of pollen contains $183 \mathrm{mg}$ of beebread, which is sufficient to rear about one bee. Based on the findings of the study the number of cell with beebread in a colony during rainy season can rear properly about 53 bees at a time. Under such situation, if large numbers of larvae are developing in a colony, they are deprived of required amount of pollen. Then the bees become physically and physiologically weak. Such bees cannot produce enough royal jelly as their hypopharyangeal glands are not properly developed and will subjected to various kinds of diseases and disorders.

\section{CONCLUSIONS}

Honey and nectar provides only energy necessary for flight and metabolism. In fact, all nutrition of honeybees, such as protein, vitamins, minerals, fats etc. comes from pollen. The development of body tissue, muscles, and glands such as hypopharyngeal glands depends upon adequate amount of protein in the honey bee diet. Proper development of brood food glands in worker bees is very important to produce sufficient quantities of royal jelly to feed the developing larvae. Therefore, lack of adequate amount of pollen in the colony reduces the brood production and colony strength. When bees are developed under the poor status of pollen, they become physically and physiologically weak, disordered and are proned to many kinds of diseases and disorders. Such bees are unable to produce enough royal jelly to feed the growing larvae and those larvae when emerges will be also physically and physiologically weak and disordered. So, there will be a chain effect on the development of weak bees especially due to the lack of pollen. Therefore, the quantity and quality of incoming pollen in the hive is critical for the production of brood and beehive products.

Worker bees collect pollen from different type of flowering plants. The amount of pollen collection is influenced by the need of the colony and external factors such as climate and availability of bee flora. There is a great difference in the amount of pollen collection and store and brood production during different seasons of Terai, Nepal. Spring season has been found the best time for the production of brood, pollen and other hive products. Autumn, winter and summer seasons are normal for the collection of pollen and brood production except in certain times and places. Rainy season has been found the worst season for bees in Terai and mid hills of Nepal. Colony population declines sharply, become physically and physiologically weak and disordered due to the nutritional deficiencies and starvation. Therefore, it is very important to feed bees sufficiently with protein rich food containing vitamins and minerals throughout the rainy season to keep bees in normal condition.

\section{ACKNOWLEDGEMENTS}

The authors express their appreciation to the National Agriculture Research and Development Funds for providing research grant to conduct this research. Sincere thanks goes to Directorate of Research and Publication, IAAS, Rampur Chitwan for providing administrative and logistic support to carryout this research. The author are also grateful to Gorkha Bee Farm, Yagyapuri and their staffs for providing all necessary tools, space and other required support to complete this experiment.

\section{REFERENCES CITED}

Camareno, J. E. and P. I. Meza . 1973. "Arginea maritima” L, Bak (Scilla maritima) evaluated by statistical methods and bee behavior to it. Proc. $24^{\text {th }}$ Intl. Beekeeping Cong., Buenos Aires. pp. 484-490. 
Dietz, A. 1975. Nutrition of adult honeybees. In: C. P. Dadant, C. C. Dadant, M. G. Dadant and J. C. Dadant (eds.) The Hive and The Honeybee. Dadant and Sons, Inc. Hamilton, USA. pp. 125-156.

Hayad, M. H. 1935. Brood rearing by honeybees confined to pure carbohydrate diet. J. Econ. Ent. 28:657-660. Louveaux, J. 1958/59. Research surla recolatedu pollen par les abeilles (Apis mellifera L.). In: C. P. Dadant, C. C. Dadant, M. G. Dadant and J. C. Dadant (eds.) The Hive and The Honeybee. Dadant and Sons, Inc. Hamilton, USA. pp. 401- 436.

Mattila, H. R. and G. Otis. 2003. The effects of spring nutritional supplements on worker quality and quantity. Final Program and Abstacts, $38^{\text {th }}$ Apimondia. Intl. Apic. Cong. Slovenia, Aug. 24-29, 2003. pp 406 (Abstract).

Mishra, R. C. and S. K. Sharma. 1997/98. Technology for management of Apis mellifera in India In: R. C. Mishra (eds.) Perspectives in Indian Apiculture. pp.131-148.

Otis, G.; D. E. Wheeler; N. Buck and H. R. Mattila. 2003. Storage proteins in winter honeybees. Final Program and Abstacts, 38 ${ }^{\text {th }}$ Apimondia. Intl. Apic. Cong. Slovenia, Aug. 24-29, 2003. pp. 710 (Abstract).

Rashad, A. E. and R. L. Parker.1958. Pollen as a limiting factor in brood rearing and honey production. Trans. Kansal. Acad. Sci. 61:237-248.

Verma, L. R 1995. Pollination ecology of apple orchards by hymenopterous insects in Matiana-Narkand temperate zone. In: P. G. Kevan (ed.) The Asiatic Hive Bees. Enviroquest, Ltd., Canada. pp.143-150.

Vivino, A.E. and E.S. Palmer. 1994. The chemical composition and nutritional value of protein collected by bees. Archs Biochem. 4:129-136.

Woyke, J. 1976. Brood rearing efficiency and absconding in Indian honeybees. J. Apic. Res. 15:123-133. 